\title{
Rediscovery of Madhuca diplostemon (Sapotaceae) - a threatened species of the Western Ghats, India, after a hiatus of 184 years
}

\author{
Shailajakumari S. ${ }^{1}$, Santhosh Kumar E.S. ${ }^{*}$, Sreekala A.K. ${ }^{1}$, Parthipan, B. ${ }^{2}$ \& R. Prakashkumar ${ }^{1}$ \\ ${ }^{1} J a w a h a r l a l$ Nehru Tropical Botanic Garden and Research Institute, Palode, Thiruvananthapuram, Kerala - 695562 , India. \\ ²Department of Botany, S.T. Hindu College, Nagaercoil P.O., Nagercoil, Tamil Nadu - 629 002, India. \\ *E-mail: santhoshkumares@gmail.com
}

\begin{abstract}
Madhuca diplostemon (C.B.Clarke) P.Royen, a threatened endemic species of the Western Ghats, is rediscovered in a sacred grove in Kollam district in Kerala, after a hiatus of 184 years since its first collection. A detailed description, photographs and relevant notes are provided.
\end{abstract}

Keywords: Endemic species, Kerala, Kollam district, Madhuca, Sacred Grove, Sapotoideae.

\section{Introduction}

The genus Madhuca Buch.-Ham. ex J.F.Gmel. (subfamily Sapotoideae), has about 100 species distributed in Bangladesh, Borneo, China, Hainan, India, Java, Laos, Malaya, Maluku, Myanmar, Nepal, New Guinea, Philippines, Sri Lanka, Sulawesi, Sumatra, Thailand and Vietnam (Mabberley 2017; POWO, 2020). In India seven species are reported viz. Madhuca bourdillonii (Gamble) H.J.Lam, M. diplostemon (C.B.Clarke) P.Royen, M. fulva (Thwaites) Macbr., M. indica J.F.Gmel., M. insignis (Radlk.) H.J.Lam, M. longifolia (Koenig) Macbr. and M.neriffolia (Moon) H.J.Lam, of which M. bourdillonii, $M$. diplostemon, and $M$. insignis are endemic to the Western Ghats (Nayar \& Sastry, 1990; Nayar et al., 2014; IUCN, 2020).

During floristic studies in the sacred groves of Kollam district in Kerala, samples assigned to Madhuca were collected from a sacred grove near

Received: 14.04.2020; Revised \& Accepted: 23.08.2020

Published Online: 30.09 .2020
Paravur in Kollam district. On critical study with authentic literature and type specimen housed at $\mathrm{K}$ and E (herbaria codes according to Thiers, 2020 continuously updated), it has been identified as $M$. diplostemon, an endemic and endangered species of the Western Ghats.

Wight (1848) first described this species in his Icones Plantarum Indiae Orientalis as Diospyros obovata Wight, based on his collection from Kollam ('Quilon') in 1835 which comprises of three specimens with immature flower buds. Later, Clarke (1882) examined Wight's specimens and found that it neither belonged to Diospyros nor to Ebenaceae, but was a close match with Isonandra of Sapotaceae. Diospyros obovata Wight is a later homonym of D. obovata Jacq. (1798), hence he described it as Isonandra diplostemon C.B.Clarke with a scanty description. However, owing to its immature floral details, he safely placed it under an anomalous species section that was also followed by Gamble (1921) in his Flora of the Presidency of Madras. Royen (1960) during his revisionary investigation of the genus Madhuca for South East Asia transferred Isonandra diplostemon to Madhuca and made a combination viz. M. diplostemon (C.B.Clarke) P.Royen. The type specimens are housed at K (K000777740, lectotype) and E (E00179201, E00277959, isolectotypes). Sadly, out of the three specimens collected by Wight, only the duplicate sheets housed at $\mathrm{E}$ have the annotation about its type locality as 'Quilon', whereas the type specimen at $\mathrm{K}$ is lacking it. Many of the later 
botanists might have consulted the type specimen housed at K thought that the specimen was collected from an imprecise locality somewhere on the Deccan Peninsula (Oldfield et al., 1998). Kollam (Quilon) was a quite large area with several luxuriant vegetations in the past. Now, most of these forests have been cleared for several development activities, and currently the original vegetation prevailed in the lowland and midland is confined to the sacred groves. Since its original collection, individuals of $M$. diplostemon were never collected again, neither from its locality nor elsewhere, and botanical explorations in Eastern and Western Ghats have failed to find the species (Nayar \& Sastry, 1990; Rakesh, 1993; Oldfield et al., 1998). Moreover, it has not been enlisted in any of the recent treatises of southern India (Nayar et al., 2006, 2014). The present collection hence forms a rediscovery of this species after a hiatus of 184 years since its first collection. A detailed description, photographs, IUCN status and relevant notes are provided in this paper.

\section{Taxonomic treatment}

Madhuca diplostemon (C.B.Clarke) P.Royen, Blumea 10: 78. 1960. Isonandra diplostemon C.B.Clarke, Fl. Brit. India 3(9): 540.1882. Diospyros obovata Wight, Icon. Pl. Ind. Orient. 4: t. 1226. 1848, nom. illeg., non Jacquin 1798. Lectotype (designated by Jeuken, 1952): INDIA, Kerala, Kollam district, Kollam (Quilon), December 1835, Robert Wight 583 (K [K000777740 digital image!]; isolecto E [E00179201, E00277959 digital images!])

Fig. 1

Small trees, up to $4 \mathrm{~m}$ high, bark fissured, blaze yellowish-white, latex thick, sticky, white; branchlets angular, 2-6 $\mathrm{mm}$ in diam., glabrous; terminal buds 2.5-3.5 mm long, sparsely ferruginous hairy, stipules minute, lanceolate, c. $1 \times 0.5 \mathrm{~mm}$, apex acute, glabrous inside, puberulous outside, caducous. Leaves more or less spirally arranged, crowded towards the branch tips, obovate, suborbicular-obovate or narrowly obovate, 3-14 × 1.5-8 cm, base rounded, abruptly narrowed to oblique, margins entire, apex rounded, retuse to obtusely acuminate, coriaceous, glabrous, dark green on the upper surface, pale on the lower surface, midrib prominent and crested on the upper surface, rounded on the lower surface; venation brochidodromous, secondary veins 10-18 pairs, prominent on both surfaces, ascendant with an angle of $65^{\circ}$, tertiary veins laxly reticulate, distinct on either side but more prominent beneath; petioles 7-14 mm long, flat-convex beneath, glabrous. Fascicles axillary, 3-8-flowered. Flowers pedicellate; pedicels $1-1.5 \mathrm{~cm}$ long, gradually thickened towards the apex, ferruginous tomentose when young, later glabrescent. Sepals 4, ovate or ovate-suborbicular, 8-10 × 6-8 mm, apex obtusely acuminate, outer sepals sparsely ferruginous hairy outside, glabrous inside, inner sepals glabrous, hyaline, margins fimbriate. Corolla campanulate, 7-8-lobed, 1.5-1.8 cm long, glabrous; lobes oblong-obovate, apex rounded. Stamens 15-19 in 2 whorls; filaments subulate, short, glabrous; anthers sagittate, apex with c. $1 \mathrm{~mm}$ long appendix. Ovary oblongoid, c. $0.5 \mathrm{~cm}$ long, superior, glabrous, 6-8; ovules 1 in each; style slender, 2-2.5 cm long, glabrous; stigma pointed. Berries ellipsoid, 2-3 $\times$ $0.8-1 \mathrm{~cm}$, beaked, glabrous. Seed one, narrowly ellipsoid, laterally compressed, $2-2.5 \times 0.6-0.8 \mathrm{~cm}$, pale brown, slightly regulate and shining.

Flowering \& fruiting: Flowering and fruiting from January to March.

Habitat: Found in a sacred grove at $40 \mathrm{~m}$ altitude. There was only one mature tree observed in front of a temple and currently protected by a retaining wall around the tree. There is no associated species in the vicinity of the tree owing to the paved tiles made by the temple authority.

\section{Distribution: Endemic to Kerala.}

Specimen examined: INDIA, Kerala, Kollam district, Koonayil Ayiravilli Siva Temple Tavu, Paravur, 22.01.2019, Shailajakumari 9909 (TBGT).

Conservation status: Madhuca diplostemon is listed as an endangered species in the IUCN Red List (IUCN, 2020). So far, only one mature individual is known. The senior author could not locate a 


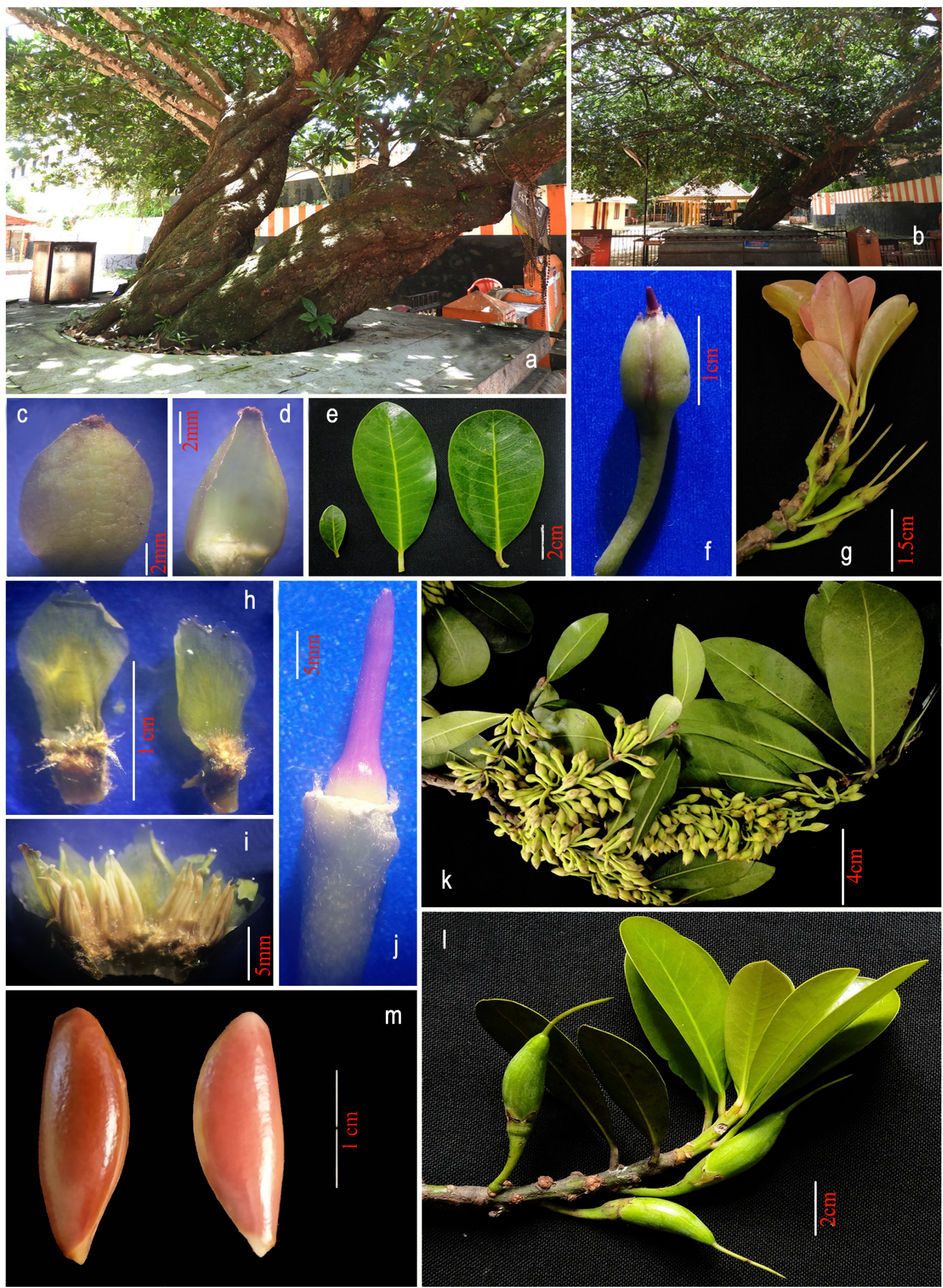

Fig. 1. Madhuca diplostemon (C.B.Clarke) P.Royen: a \& b. Habit; c. Outer sepal-lower surface; d. Outer sepal-upper surface; e. Leaves; f. Flower bud; g. Young shoot with flowers; h. Portion of corolla showing lobes (left-outer corolla lobe, right-inner corolla lobe); i. Stamens attached to corolla; j. Pistil with part of style removed; k. Flowering twig with buds; I. Twig with fruits; m. Seeds showing both surfaces (photos by E.S. Santhosh Kumar). 
second locality of this species despite thorough surveys in more than 1100 sacred groves spread across Kollam district. It is believed that the species was a highly local endemic with a few individuals in the past, which were inadvertently removed for temple expansion in recent years. We have observed a name board on this tree denoted as Madhuca neriifolia during our initial surveys. This indicated that the temple authorities might have overlooked this endangered species as a common Attilippa ( $M$. neriifolia) and cleared the rest of the individuals for temple expansion. Since the species is represented by a single mature individual in a single locality, it is assessed here as Critically Endangered, as per IUCN criteria B2ab(iii) and D (IUCN, 2019).

Notes: Based on morphological and molecular data, Swenson and Anderberg (2005) recognized three subfamilies for Sapotaceae viz. Sarcospermatoideae, Sapotoideae and Chrysophylloideae. The subfamily Sapotoideae has two recognized tribes: Sapoteae and Sideroxyleae, of which Sapoteae includes the formerly recognized subtribes Manilkarinae and Mimusopinae but excludes Glueminae (Mimusopeae) and one part of the tribe Isonandreae. Since Isonandreae is polyphyletic, certain genera previously belonging to this tribe, such as Madhuca, Palaquium Blanco, Payena A.DC., are now included in Sapoteae because of their strong morphological and cladistic support. Now, tribe Sapoteae has eleven genera, of which Madhuca, Manilkara Adans., Mimusops L. and Palaqium occur in India.

Madhuca diplostemon is morphologically similar to $M$. insignis, another endangered species of the Western Ghats, but differs from it by having glabrous young shoots (rusty sericeous), lanceolate stipules (lanceolate-subulate), branchlets with coriaceous leaves sub-conferted towards the tip (sub-coriaceous leaves scattered throughout the branchlets), obovate, sub-orbicular-obovate to narrowly obovate lamina (obovate to oblanceolateoblong), ovate or ovate to sub-orbicular sepals with sparsely ferruginous hairs (ovate sepals with rusty sericeous hairy) and the oblongoid ovary (ovoid ovary). Since the present description of $M$. diplostemon derived from a single tree located in a sacred grove, we admit that the ranges of variations in morphological characters are quite limited. This can be addressed when more individuals are raised from seeds or located elsewhere. Jawaharlal Nehru Tropical Botanic Garden and Research Institute (JNTBGRI) is planning to undertake ex situ conservation activities for this species through its species recovery programme.

\section{Acknowledgements}

The authors are thankful to KSCSTE for the facilities provided. The senior author is grateful to the authorities of Manonmaniam Sundaranar University for the logistic supports.

\section{Literature Cited}

CLARKE C.B. 1882. Sapotaceae. In: HOOKER J.D. (ed.) Flora of British India. Volume 3. L. Reeve and Co., London. pp. 534-549.

GAMBLE J.S. 1921. Flora of the Presidency of Madras. Adlard \& Co., London.

IUCN 2019. Guidelines for Using the IUCN Red List Categories and Criteria. Version 14. Prepared by the Standards and Petitions. IUCN, Gland and Cambridge. Downloadable from http://www.iucnredlist.org/ documents/RedListGuidelines.pdf.

IUCN 2020. IUCN Red List of Threatened Species. Version 2020.1. Available at: www.iucnredlist.org. (Accessed on 11.04.2020).

JACQUIN N.J. 1798. Plantarum rariorum horti caesarei schoenbrunnensis. Volume 3. C.F. Wappler, Vienna.

JEUKEN M. 1952. Monograph of the genus Isonandra. Blumea 6 (3): 547-579.

MABBERLEY D.J. 2017. Mabberley's Plant Book: A portable dictionary of plants, their classification and uses. Fourth edition. Cambridge University Press, Cambridge. https:/ /doi.org/10.1017/9781316335581

NAYAR M.P. \& A.R.K. SASTRY 1990. Red data book of Indian plants. Volume. 3. Botanical Survey of India, Calcutta.

NAYAR T.S., RASIYA BEEGAM A., MOHANAN N. \& G. RAJKUMAR 2006. Flowering Plants of the Kerala A Handbook. Jawaharlal Nehru Tropical Botanic Garden and Research Institute, Palode. 
NAYAR T.S., BEEGAM A.R.\& M. SIBI 2014. Flowering plants of the Western Ghats, India. Volume. 1. Jawaharlal Nehru Tropical Botanic Garden and Research Institute, Palode.

OLDFIELD S., LUSTY C. \& A. MACKINVEN 1998. The World List of threatened Trees. World Conservation Press, Cambridge.

POWO 2020. Plants of the World Online. Facilitated by the Royal Botanic Gardens, Kew. Published on the Internet: http://plantsoftheworldonline.org/ (Accessed on 11.04.2020).

RAKESH K. 1993. Taxonomic Studies on Indian Sapotaceae. Ph.D. Thesis (unpublished), University of Calcutta, Kolkata.
ROYEN VAN P. 1960. Revision of the Sapotaceae of the Malaysian area in a wider sense XX, Madhuca Gmel. Blumea 10: 1-117.

SWENSON U. \& A.A. ANDERBERG 2005. Phylogeny, character evolution, and classification of Sapotaceae (Ericales). Cladistics 21: 101-130. https://doi.org/ 10.1111/j.1096-0031.2005.00056.x

THIERS B. 2020 continuously updated. Index Herbariorum: a global directory of public 22 herbaria and associated staff. New York Botanical Garden's Virtual Herbarium. Available at: http://sweetgum.nybg.org/science/ih/ (Accessed 20.08.2020).

WIGHT R. 1848. Icones Plantarum Indiae Orientalis, or Figures of Indian Plants. Volume 4. J.B. Pharoah, Madras. 